\title{
NOTES ON THE VERTICAL DISTRIBUTION OF THE HUMAN SWEAT GLANDS
}

\author{
SHUNZO TAKAGI AND KO TŌBARU* \\ Institute of Physiology, School of Medicine, University of Nagoya $\dagger$
}

The distribution of sweat glands over the human body has so far been investigated in the dimension of area, and we have no general idea how deep they are distributed in the skin. In 1943, Kuno and his collaborators (3) expressed the opinion that chloride would be accumulated in the skin during the activity of sweat glands. The truth of this assumption has been confirmed with more certainty by Yoshimura and Chihaya (unpublished), who measured the chloride content in the skin tissue by means of $\mathrm{Ag}-\mathrm{AgCl}$ electrodes. The chloride may presumably be accumulated in the immediate neighbourhood of the glomeruli of sweat glands, or more diffusely in the layers of skin tissues where the glomeruli are situated. For consideration of the amount of the accumulated chloride, the total volume of these skin layers, which can be estimated by the vertical distribution of the sweat-gland glomeruli, seems to be useful. The following investigation was therefore performed.

\section{MATERIALS AND METHOD}

Skin samples of 33 regions of the body, as specified in table 1, were taken from the corpse of a Japanese male of 30 years old, who died an accidental death. The samples were fixed in 10 per cent formalin, embedded in celloidin and cut into sections 15 micra thick. The sections were stained with Delafield's hematoxylin and eosin.

Observations of sweat glands were made with 2-3 pieces of the skin about $100 \mathrm{sq} . \mathrm{mm}$. for each of the 33 regions above mentioned and about 10 sections from each piece were investigated under the microscope. The principal purpose of the observation was to estimate the upper and lower margin of the group of the sweat-gland glomeruli present in the concerned areas of the skin. Among the sweat glands found in each specimen, the exceptionally short or long ones, which were situated singly out of the ordinary group, were left out of account.

With the remainder, the perpendicular, straight line distance from the surface of the skin to the upper end of the glomerulus of the shortest sweat gland and that to the lower end of the glomerulus of the longest gland were determined. The difference between the two indicates the thickness of the skin layers where all the sweat-gland glomeruli are present. The average difference obtained from all the specimens of one area of the skin was regarded to repre-

Received for publication July 1, 1953

* 高木俊蔵, 唐原 功 Osaka.

† The present address of the authors: Department of Biology, Naniwa University, Sakai, 
sent the average thickness of the skin layers containing the sweat-gland glomeruli for that area of the skin.

\section{RESULTS}

The vertical distributions of the sweat glands in the different regions of the body are shown in table 1 . In the table, the different regions of the skin are arranged in the order of magnitude of the depth of the longest sweat gland. In the fourth column of the table, figures of the thickness of the skin are given, which implies the thickness of tissue from the surface of the skin to the boundary between the corium and the subcutaneous tissue. This boundary is considered conveniently to be at a level bisecting the distance between the highest and the lowest upper margins of the adipose tissue.

TABLE 1. Vertical Distribution of the Sweat Glands

\begin{tabular}{|c|c|c|c|}
\hline \multirow[b]{2}{*}{ Regions } & \multicolumn{2}{|c|}{$\begin{array}{l}\text { Distance (mm.) from the } \\
\text { skin surface to }\end{array}$} & \multirow{2}{*}{$\begin{array}{l}\text { Thickness } \\
\text { of the } \\
\text { skin } \\
(\mathrm{mm} .)\end{array}$} \\
\hline & $\begin{array}{l}\text { The upper end of } \\
\text { glomerulus of the } \\
\text { shortest gland }\end{array}$ & $\begin{array}{l}\text { The lower end of } \\
\text { glomerulus of the } \\
\text { longest gland }\end{array}$ & \\
\hline $\begin{array}{l}\text { Sole of the foot } \\
\text { Front of the neck } \\
\text { Side of the head } \\
\text { Middle on the back of the waist } \\
\text { Middle of the back }\end{array}$ & $\begin{array}{l}2.60 \\
1.17 \\
1.04 \\
1.69 \\
1.82\end{array}$ & $\begin{array}{l}5.07 \\
4.29 \\
4.03 \\
3.98 \\
3.90\end{array}$ & $\begin{array}{l}4.0 \\
2.4 \\
3.6 \\
4.0\end{array}$ \\
\hline $\begin{array}{l}\text { Undersurface of the hips } \\
\text { Flexor side of the thigh } \\
\text { Breast just under the nipple } \\
\text { Breast above the nipple } \\
\text { Abdomen }\end{array}$ & $\begin{array}{l}1.61 \\
0.78 \\
1.17 ? \\
1.17 \\
1.17\end{array}$ & $\begin{array}{l}3.90 \\
3.64 \\
3.38 ? \\
3.12 \\
3.12\end{array}$ & $\begin{array}{l}4.0 \\
3.2 \\
2.4 \\
2.4 \\
-\end{array}$ \\
\hline $\begin{array}{l}\text { Outer surface of the thigh } \\
\text { Inner surface of the thigh } \\
\text { Inner surface of the shin } \\
\text { Back of the head } \\
\text { Abdomen just under the navel }\end{array}$ & $\begin{array}{l}0.78 \\
1.04 \\
0.91 \\
1.04 \\
1.04\end{array}$ & $\begin{array}{l}3.12 \\
3.12 \\
3.12 \\
3.12 \\
3.12\end{array}$ & $\begin{array}{l}2.8 \\
2.8 \\
3.2 \\
2.8 \\
2.8\end{array}$ \\
\hline $\begin{array}{l}\text { Flexor side of the fore-arm } \\
\text { Extensor side of the thigh } \\
\text { Palm of the hand } \\
\text { Forehead } \\
\text { Dorsal surface of the hips }\end{array}$ & $\begin{array}{l}0.81 \\
0.65 \\
1.04 \\
1.17 \\
1.04 ?\end{array}$ & $\begin{array}{l}3.02 \\
2.99 \\
2.99 \\
2.89 \\
2.86 ?\end{array}$ & $\begin{array}{l}2.4 \\
2.8 \\
1.6 \\
2.8 \\
2.8\end{array}$ \\
\hline $\begin{array}{l}\text { Axilla } \\
\text { Flexor side of the upper arm } \\
\text { Outer surface of the shin } \\
\text { Top of the head } \\
\text { Side of the neck }\end{array}$ & $\begin{array}{l}0.65 \\
1.04 \\
0.65 \\
1.43 \\
1.17\end{array}$ & $\begin{array}{l}2.78 \\
2.73 \\
2.73 \\
2.73 \\
2.52\end{array}$ & $\begin{array}{l}2.4 \\
2.8 \\
2.4 \\
2.8 \\
2.4\end{array}$ \\
\hline $\begin{array}{l}\text { Extensor side of the fore-arm } \\
\text { Dorsal surface of the hand } \\
\text { Middle of the breast } \\
\text { Extensor side of the upper arm } \\
\text { Cheek }\end{array}$ & $\begin{array}{l}0.73 \\
0.52 \\
0.78 \\
0.18 \\
0.83\end{array}$ & $\begin{array}{l}2.47 \\
2.47 \\
2.42 \\
1.95 \\
2.19\end{array}$ & $\begin{array}{l}2.4 \\
2.0 \\
\frac{2.4}{2.4}\end{array}$ \\
\hline $\begin{array}{l}\text { Flexor side of the shin } \\
\text { Dorsal surface of the foot }\end{array}$ & $\begin{array}{l}0.52 \\
0.39\end{array}$ & $\begin{array}{l}1.95 \\
1.82\end{array}$ & $\begin{array}{l}1.6 \\
2.0\end{array}$ \\
\hline $\begin{array}{l}\text { Side of the breast under the } \\
\text { axilla }\end{array}$ & $1.17 ?$ & $1.77 ?$ & 2.8 \\
\hline
\end{tabular}

Note: The figures with? are not much reliable, because they were obtained from observations on a few number of sections.

The regions, of which the figures are not given in the fourth column, lacked the adipose tissue in the sections. 


\section{The Depth of the Sweat Glands}

Largely speaking, the lower margin of the glomerulus of the longest gland is situated in the large number of the regions of the body from 2.4 to $3.1 \mathrm{~mm}$. below the surface of the skin, although it is much deeper in some regions and shallower in the others (see the third column in table 1).

Remarkable is the fact that the sweat glands on the sole of the foot reach very deep, i.e. $5.07 \mathrm{~mm}$., under the surface of the skin. It must be acknowledged that the epidermis is very thick in this region. But even if its thickness is subtracted from the depth of the glands, they are still among the longest sweat glands of the body. In our material, the epidermis over the general body surface was $0.1-0.4 \mathrm{~mm}$., whereas it measured $1.3-1.7 \mathrm{~mm}$. over the sole of the foot and $0.6-0.7 \mathrm{~mm}$. over the palm of the hand.

In most regions of the body, the figure indicating the depth of the longest sweat gland is not very different from that of the thickness of the skin. Microscopic observation shows in reality that the glomeruli of the longer sweat glands are either located on the upper boundaries of the adipose tissue or slightly embedded in it. It will, however, be noted that, in three regions, namely the sole of the foot, the palm of the hand and the side of the head, the depth of the longest sweat gland is much greater than the thickness of the skin, the difference being about $1.1 \mathrm{~mm}$., $1.4 \mathrm{~mm}$. and $1.6 \mathrm{~mm}$. respectively. In these regions the glomeruli of long sweat glands are all embedded in the adipose tissue and some of them attain its lower boundaries.

The level, at which the upper end of the glomerulus of the shortest gland is situated, is from 0.5 to $1.2 \mathrm{~mm}$. below the skin surface in most of the regions (see the second column in table 1). It is often much deeper in those regions, where the glomerulus of the longest gland is deeply situated.

\section{The Thickness of the Tissue Layer Containing the Sweat-Gland Glomeruli}

In each region, the figure showing the distance from the skin surface to the upper end of the glomerulus of the shortest gland was subtracted from the figure of the depth of the longest gland. The value obtained will indicate the thickness of the tissue layer containing all the glomeruli in the respective region. It may be called conveniently the glomerulus layer. The thicknesses of these layers in different skin regions are summarized in table 2 , in their descending order.

The glomerulus layer may be said to be from 1.4 to $2.4 \mathrm{~mm}$. in thickness in most of the regions. In most regions, its thickness varies correspondingly to the depth of the longest gland. But this is not always true, as, in some parts of the skin, the uppermost glomerulus is located relatively deep.

\section{The Approximate Volume of the Tissue Containing the Glomeruli}

For estimation of the total volume of the glomerulus layer, we have to know how large area of the body surface is covered by each representative skin region, indicated in the tables. Unfortunately the body surface of the subject employed in this investigation being not known, this volume as related to this subject cannot be calculated. But granted that the figures shown in table 2 can represent the thickness of glomerulus layer adoptable to most Japanese 
TABLE 2. Thickness of the Tissue Layer Containing the Sweat-Gland Glomeruli

\begin{tabular}{l|c||l|c}
\hline \multicolumn{1}{c|}{ Regions } & $\begin{array}{c}\text { Thickness } \\
(\mathrm{mm} .)\end{array}$ & \multicolumn{1}{|c}{ Regions } & $\begin{array}{c}\text { Thickness } \\
(\mathrm{mm})\end{array}$ \\
\hline Front of the neck & 3.12 & Breast above the nipple & 1.95 \\
Side of the head & 2.99 & Abdomen & 1.95 \\
Flexor side of the thigh & 2.86 & Dorsal surface of the hand & 1.95 \\
Sole of the foot & 2.47 & Palm of the hand & 1.95 \\
Outer surface of the thigh & 2.34 & Dorsal surface of the hips & $1.82^{*}$ \\
Extensor side of the thigh & 2.34 & Extensor side of the upper arm & 1.77 \\
Middle on the back of the waist & 2.29 & Extensor side of the fore-arm & 1.74 \\
Undersurface of the hips & 2.29 & Forehead & 1.72 \\
Flexor side of the fore-arm & 2.21 & Flexor side of the upper arm & 1.69 \\
Inner surface of the shin & 2.21 & Middle of the breast & 1.64 \\
Breast just under the nipple & 2.21 & Flexor side of the shin & 1.43 \\
Axilla & 2.13 & Dorsal surface of the foot & 1.43 \\
Middle of the back & 2.08 & Cheek & 1.36 \\
Inner surface of the thigh & 2.08 & Side of the neck & 1.35 \\
Outer surface of the shin & 2.08 & Top of the head & 1.30 \\
Back of the head & 2.08 & Side of the breast under the & $0.60 * *$ \\
Abdomen just under the navel & 2.08 & axilla & \\
\hline
\end{tabular}

* In this region, the depth of the longest gland could not be determined exactly. The figure is thus not much reliable.

** The figure is not reliable as only a few sweat glands were encountered in this region.

TABLE 3. The Volume of the Tissue Containing Sweat-Gland Glomeruli

\begin{tabular}{l|c|c|c|c|c}
\hline \multicolumn{1}{|c|}{ Division } & Percentage & $\begin{array}{c}\text { Surface } \\
\text { area } \\
\text { (sq. cm.) }\end{array}$ & Regions included & $\begin{array}{c}\text { Thickness } \\
\text { of the } \\
\text { glomerulus } \\
\text { layer } \\
\text { (mm.) }\end{array}$ & $\begin{array}{c}\text { Volume of the } \\
\text { tissue contain- } \\
\text { ing the } \\
\text { glomeruli } \\
\text { (cc.) }\end{array}$ \\
\hline $\begin{array}{c}\text { Head covered } \\
\text { with hairs }\end{array}$ & 4.3 & 688 & $\begin{array}{c}\text { Top, Back and Side of } \\
\text { the head }\end{array}$ & 2.12 & 146 \\
\hline Face & 3.1 & 496 & Forehead, Cheek & 1.54 & 76 \\
\hline Neck & 2.4 & 384 & $\begin{array}{c}\text { Front and Side of the } \\
\text { neck }\end{array}$ & 2.24 & 86 \\
\hline Upper arms & 8.2 & 1,312 & $\begin{array}{c}\text { Extensor and Flexor } \\
\text { side of the upper } \\
\text { arm }\end{array}$ & 1.73 & 227 \\
\hline Fore-arms & 6.1 & 976 & $\begin{array}{c}\text { Extensor and Flexor } \\
\text { side of the fore-arm }\end{array}$ & 1.98 & 193 \\
\hline Hands & 5.3 & 848 & $\begin{array}{c}\text { Dorsal surface and } \\
\text { Palm of the hand }\end{array}$ & 1.95 & 165 \\
\hline Upper part of \\
the trunk
\end{tabular}


adults, the following calculation may be made.

According to Shintani (4), the body surface of a Japanese of an ordinary constitution, with a stature of $160 \mathrm{~cm}$. and a body weight of $55 \mathrm{~kg}$., may safely be estimated to be about 1.6 square meters. The same author (5) divides the body surface in eleven divisions and gives their areas in percentages of the whole body surface on the ground of direct measurement on ten adult male individuals. They are given in the second column in table 3. In the third column are given the areas of the different divisions in sq. $\mathrm{cm}$., the total body surface of $1.6 \mathrm{sq}$. $\mathrm{m}$. being divided according to the ratio given in the preceding column.

For the computation of the volume of the glomerulus layer, it is required to know its average thickness for each skin division. As each division includes two to four regions of our measurement, as mentioned in the fourth column, the mean of the figures for the corresponding regions, shown in table 2, was used to indicate the average thickness of the glomerulus layer of the concerned skin division (fifth column). The volumes of the glomerulus layers, thus calculated for eleven skin divisions, are given in the sixth column. The sum of these figures, i.e. the total volume of the skin tissue containing the sweat-gland glomeruli, amounts roughly to $3,200 \mathrm{cc}$.

\section{DISCUSSION}

As to the locality where the human sweat-gland glomeruli are situated, an idea such as stated by Aurel (1) that they are either on the boundary between the corium and the subcutaneous tissue, or within the latter seems to be prevailing. According to the above results of our investigation, however, it seems to be more correct to say that the sweat glomeruli are located either in the corium or along its boundary with the subcutaneous tissue. A notable exception is found in the palms and soles, where most sweat glomeruli are located deeper in the subcutaneous adipose tissue. The axilla was first suspected to show some peculiarity in the distribution of sweat glomeruli as there are both apocrine and eccrine glands. But all the apocrine glomeruli being present in the intermediate zone of the layers where the eccrine glomeruli are distributed, their general situation is similar to that of the general body surface.

As above stated, the total volume of the tissue containing the sweat glomeruli may be estimated at $3,200 \mathrm{cc}$. The question arises how much chloride may be accumulated in this tissue when perspiration is in progress. The extracellular chloride space may roughly be estimated to be one half of this volume of tissue, or 1.6 liters (Harrison, Darrow and Yannet (2)). According to Yoshimura and Chihaya's observations, the extent of increase in chlorine concentration in the extracellular fluid of the skin during sweating varies considerably in different seasons. In cool seasons when the increase is most prominent, the chlorine concentration may reach 0.55 per cent, i.e. 0.2 per cent higher than that before sweating. An increase of 0.1 per cent of chlorine may therefore be expected to occur often. $1.6 \mathrm{~g}$. of chlorine, or $2.6 \mathrm{~g}$. of common salt, must be accumulated in 1.6 liters of extracellular fluid for increasing its chlorine concentration by 0.1 per cent. The skin may therefore play a significant role as a 
temporary depot of chloride.

\section{SUMMARY}

The vertical distribution of the sweat glands has been measured on 33 representative regions of the skin of a corpse. The distance from the skin surface to the lower end of glomerulus of the longest gland varies from 2.4 to $3.1 \mathrm{~mm}$. in the large number of the regions. It is generally the greater, the greater the thickness of the skin. The distance from the skin surface to the upper end of glomerulus of the shortest gland is from 0.5 to $1.2 \mathrm{~mm}$. in most of the regions (table 1).

The thickness of the tissue layer, which contains all the sweat-gland glomeruli in each region, has been calculated from the above data. It is from 1.4 to $2.4 \mathrm{~mm}$. in most of the regions (table 2).

The total volume of the tissue containing sweat-gland glomeruli was estimated to be approximately 3,200 cc. (table 3).

\section{REFERENCES}

1. AUREL, G. Z. mikrosk.-anat. Forsch. $44: 56,1938$.

2. HaRrison, H. E., DaRRow, D. C. AND YANNeT, H. J. Biol. Chem. 113: 515, 1935.

3. Kuno, Y., TAkagi, S., Itō, S., Suzuki, T. And Katō, S. J. Jap. Physiol. Soc. (Japanese) $8: 550,1943$.

4. SHINTANI, J. Kokumin-Eisei (Japanese) 8: 233, 1931.

5. SHINTANI, J. ibid. 8: 440, 1931. 